kidnapping of three innocent Israeli teenagers and the permanent firing of thousands of rockets from Gaza to Israel proved that Hamas never intended to live up to what it had promised.

Hamas is a highly sophisticated terror organization to the extent that it uses women and children as human shields. It knows that any civilian casualties caused by Israel will create a huge worldwide condemnation and will turn the public opinion against Israel and in favor of Hamas. Ultimately, it has the same goal and uses the same measures as the terror militia IS, for example when Hamas publicly executed various alleged collaborators of Israel.

During the last round of fighting, Israel agreed to all the eleven proposals for a ceasefire. Hamas rejected them all. No country in the world would put up with constantly being under attack for years. Israel has the right and the obligation to defend itself and to respond with precise military operations that target Hamas terrorists and their infrastructure. It is unprecedented that the Israeli army warns civilians in Gaza with phone calls, SMS or leaflets and other means in advance of the attacks. Hamas however calls upon the population to ignore these warnings from Israel and forces them to remain in the areas which are to be attacked. Hamas located its military command centers in hospitals, uses schools as weapons depots and places their rocket launchers directly in residential areas, playgrounds, in private homes and in mosques. They even dress up in women's clothes as a cover-up carrying weapons under the gowns.

In recent years Hamas has built a network of "terror tunnels" underneath residential areas in the Gaza Strip, which reach Israeli territory under the border. The Israeli army discovered more than 30 of these tunnels and was able to avoid several attacks before terrorists could cause possible bloodbaths in Israeli villages and cities. The international community, including Europe and Germany, must ask themselves where the international aid has gone which Hamas has received over the years. Have they invested in the construction of schools and hospitals, or in the construction of tunnel systems for terrorist attacks on Israel? The answer is quite obvious.

So where do we go from here? Israel does not and will not talk to terrorists; one has to fight them. The sooner you weaken or can get rid of them the better, because they will not stop with their terror. Israel is happy to see that the world is slowly but surely dealing with the problem of the terror militia IS in Iraq accordingly. Once you do weaken or remove them, you have to try to help the current regimes to stabilize themselves and go with them step-by-step and side-by-side towards introducing them to Western values. Naturally every country in the world has its own flavor or version of democracy. And the same should apply to the Middle East. The Western World must understand that this process is different for everyone, so one must keep in mind that the pace of this process will also be different in the Middle East. It took Europe several hundred years to get to where it is now, so no one can expect a democratic change overnight from the Middle East. It will be a long way toward the absorption of progress and modern values in this region. And regarding Hamas we must make sure that it stays weakened. We must also try to reinstate the Palestinian Authority (PA) in the Gaza strip and this time around all measures must be taken in order to secure the disarmament of Hamas. For this, help of the international community is needed. Only a weakened Hamas will enable the region to move forward and negotiate an agreement to end this conflict that is going on for far too long.

\title{
Tackling the Root Causes of the Palestine/Israel Question: Towards a more Active European Role
}

\author{
Khouloud Daibes*
}

\begin{abstract}
The achievement of peace in Palestine/Israel requires an understanding of the broader context, beginning with the asymmetry between the two parties. More than twenty years of negotiations have shown that Israel, as the stronger party, which benefits from its occupation of Palestinian land, has little incentive to reach a just solution. The international community has the ability and the responsibility to provide the necessary external incentives. Europe's clear policy on the two-state solution should lead to more active support for its realization. Peace will remain elusive as long as the imbalance between the parties remains. Any lasting solution must guarantee justice, freedom and equality for all.
\end{abstract}

Keywords: Israel-Palestine conflict, negotiations, peace, Europe's role

Stichworte: Israel-Palästina-Konflikt, Verhandlungen, Frieden, Europas Rolle

\section{Root Causes and Prolongation}

\subsection{Understanding the context: An imbalance of power and a lack of will}

$\mathrm{T}$

The original cause of the current situation in Palestine/ Israel can be traced back to a single act: the creation and imposition of a foreign state on the homeland of another people. This event, in 1948, led to the forced exile of two thirds of a population and ongoing systematic discrimination against those who managed to remain in their homes. From 1967 onwards, the occupation of the rest of Palestine resulted in the subjugation of what is now a further 4.5 million people.

\footnotetext{
Dr. Khouloud Daibes is the Palestinian Ambassador to Germany.
} 
This is now a well-documented history, ${ }^{1}$ and yet one that is difficult to acknowledge for those who adopted the Zionist narrative of Palestine as "a land without a people for a people without a land". A just peace requires all parties to come to terms with the past and seek a solution based on that reality. While Palestine has been forced to come to terms with the existence of the state of Israel, and with it, the loss of 78\% of a national homeland, Israel is yet to end its occupation of the remaining $22 \%$, in order to allow both parties to live side by side in peace.

The prolongation of the 'Israeli-Palestinian conflict', as it is commonly described, rests, in part, on the word 'conflict'. This seemingly innocuous term is a misnomer, which conceals a basic truth of the situation in Palestine/Israel: the deep asymmetry between the two parties. The implication of two equal sides, fighting over land, obscures both understanding and the possibility for a solution. Predominant political and media discourse often fails to convey this reality and, with it, one of the underlying reasons preventing peace: a lack of will from the stronger party.

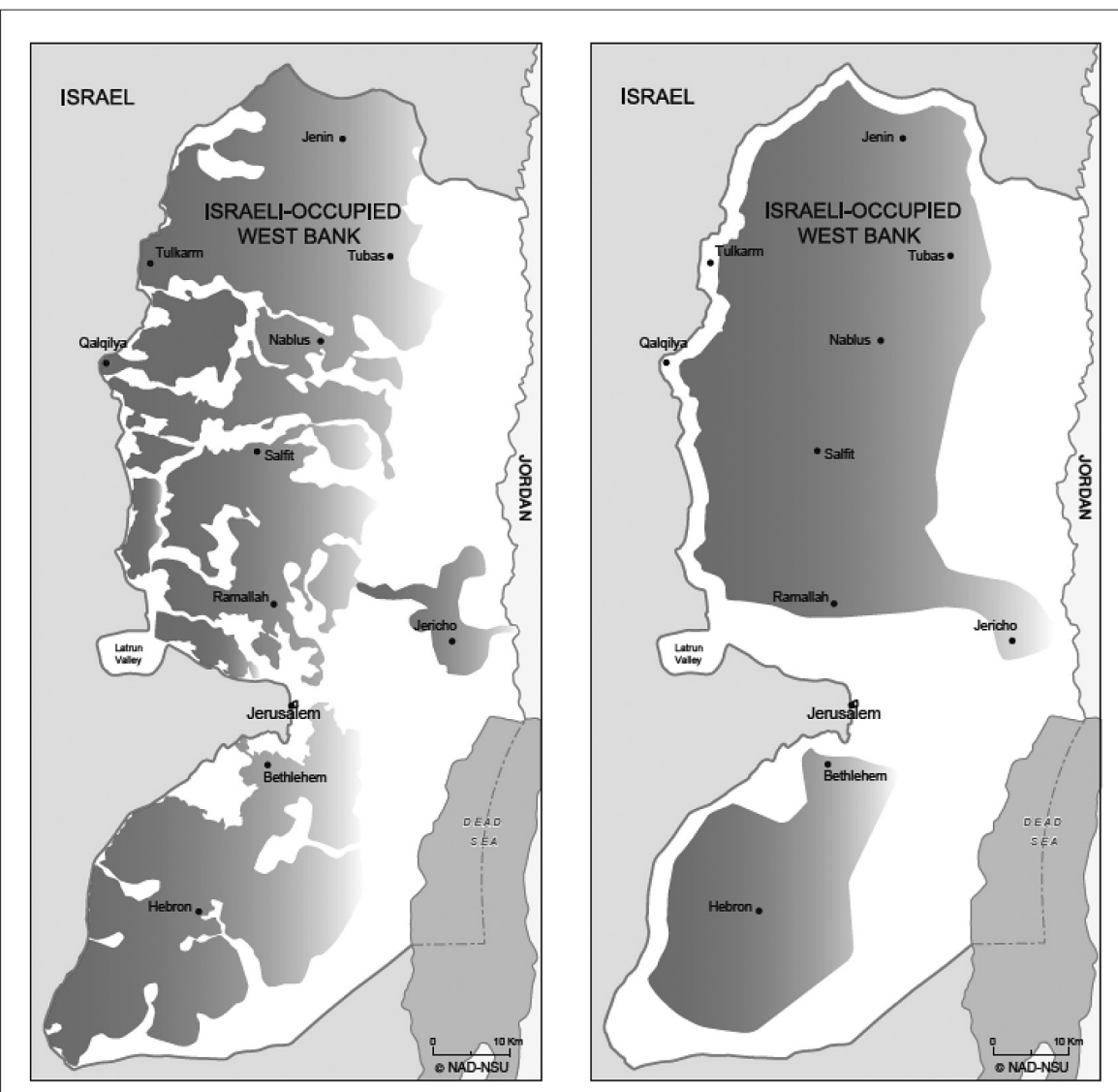

The map on the left shows the situation today, areas in white are under full Israeli control. The map on the right shows General Allon's plan from 1967.

An awareness and acknowledgement of this reality will help all parties seeking to find a lasting solution. The present article therefore aims to demonstrate how these two elements - an imbalance of power and lack of will from the stronger party - have prevented a solution thus far, and how recent developments mean that more active involvement from the international community is required. The final section focuses on Europe, by proposing concrete steps that can be taken, in order to work towards a just and lasting peace for Palestinians and Israelis alike.

\subsection{Negotiating with one's occupier: A flawed process}

In 1988, the Palestine Liberation Organisation (PLO) announced its acceptance of the two-state solution, which is based on the withdrawal by Israel from the territory it occupied in 1967, as stipulated in UN Security Council Resolutions 242 and 338. In doing so, the PLO formally conceded $78 \%$ of what was Palestine before 1948, with the understanding that, in return, Israel would end its occupation of the West Bank and the Gaza Strip and its annexation of East Jerusalem, as stipulated under international law. ${ }^{2}$

1 By Palestinian and Israeli scholars alike; see, for example, works by Edward Said, Rashid Khalidi, Ilan Pappe and Avi Shlaim.

2 In particular resolutions 476 and 478 , which deemed all of Israel's actions that aimed to alter the character of Jerusalem to be "null and void".
Through an exchange of letters at the beginning of the Oslo Process, ${ }^{3}$ in 1993, Palestine formally recognised the State of Israel. Israel agreed to recognise the PLO as the representative of the Palestinian people, but has never recognised Palestine as a state. This exchange is emblematic of what would become the general tone of the Middle East Peace Process, whereby the reality of being the weaker party has dictated flexibility and concessions primarily from one side. ${ }^{4}$

Prior to 1993, Israel had begun a process of entrenching its occupation through the transfer of parts of its civilian population to the land it occupied, in violation of Article 49 of the Fourth Geneva Convention. By 1993, Israeli settlers, those living illegally in the Gaza Strip and the West Bank, which includes East Jerusalem, numbered approximately 198000. Today, that number stands at over 540000.

The guiding principle for most Israeli governments dates back to 1967, when Israel occupied the West Bank. At the time, direct annexation of the whole area into Israel would mean the inclusion of almost one million Christian and Muslim Palestinians, who were seen as a demographic threat to the 'Jewish State'. ${ }^{5}$ Yigal Allon, an Israeli army general turned

3 UNISPAL, http://unispal.un.org/UNISPAL.NSF/0/36917473237100E28525 7028006COBC5, accessed 19/08/14.

4 Palestinian positions are transparent and available from the PLO Negotiations Affairs Department (NAD) www.nad-plo.org, under the various final status issues tabs.

5 Chomsky, N. 'Fateful Triangle: The United States, Israel and the Palestinians', 1999, pp. 47-49. 
politician, proposed a solution based on the premise that Israel would take as much land and as many natural resources as possible, with as few Palestinians as possible. ${ }^{6}$ The maps above demonstrate how the Allon plan, or a version of it, has been gradually, although unofficially, implemented since 1967.

Negotiations have taken place intermittently for over twenty years. During that time, the two-state solution has become increasingly difficult to reach, due mainly to the increase and expansion of Israeli settlements. Particularly in and around occupied East Jerusalem, intensified building of settlements around the eastern part of the city aims to sever it from the rest of the West Bank. This has severely impacted negotiations, both in terms of trust between the parties and through the creation of 'facts on the ground', which prejudice the outcome of talks. Moreover, the process itself has bought time for Israel to accelerate its settlement activity.

For negotiations to succeed, a credible and robust process is required. Those outside of the room have a significant role to play in the creation of such a process. To begin with, negotiations must have clear parameters or 'rules of the game' in order to give legitimacy to the process and prevent either party from attempting to 'move the goalposts', as it were. International law, as the basis of relations between states, should play an integral role in establishing parameters. Secondly, negotiations between an occupying power and occupied people need a mediator, or mediators, who can allow the two parties to negotiate from an equal basis, and who can ensure that any commitments or agreements are subsequently implemented. Finally, both parties must be committed to the same broad final goal. Without these three elements, a negotiated solution will remain elusive.

\section{Recent Developments and the Current Situation}

\subsection{A shift in Israeli society and its impact on the prospects of peace}

Prime Minister Netanyahu's decision to form a coalition at the far right of the political spectrum and to promote settlers to a number of key posts, including Foreign Minister, Speaker of the Knesset, Housing Minister, and others, betrays the current Israeli government's intentions regarding the two-state solution. Of the 68 members in the ruling coalition, at least 28 have clearly and unequivocally declared that they oppose any form of two-state solution: this number includes sixteen Likud-Beiteinu MKs and twelve Jewish Home MKs. ${ }^{7}$

The current Israeli government has been particularly outspoken against peace on the basis of two states. At a ceremony marking the creation of a new settlement in August 2013, Housing Minister Uri Ariel stated: "There are no two states west of the Jordan River, and there won't be two states... Even if there are negotiations taking place - this is not on the agenda." ${ }^{8}$ In January 2014, the Israeli newspaper, JPost, quoted Economy

6 McMahon, S. F. 'The Discourse of Palestinian-Israeli Relations', 2010, pp. 136-137.

7 PLO NAD, 'Netanyahu's Government Coalition: An Anti-Peace Block', February 2013.

8972 Magazine, 'In the West Bank, a new settlement is born', August 2013.
Minister Naftali Bennett explaining that, "The goal is to torpedo any agreement and prevent deterioration to pre-1967 lines." 9 In the same month, Prime Minister Netanyahu was telling an audience at the Davos conference: "I do not intend to evacuate any settlements or uproot a single Israeli."10

Settlement has been encouraged and incentivized by successive Israeli governments through loans, grants, subsidies and tax breaks. According to a 2002 survey by an Israeli human rights organization, $77 \%$ of settlers cited their primary reason for moving to a settlement as being for 'quality of life', i.e. economic purposes. ${ }^{11}$ Today, benefits for settlers come through eight separate Israeli ministries in the areas of Housing, Lands, and Education, among others. ${ }^{12}$

The growth of settler populations, increased representation at the government level and active encouragement from Israeli officials have helped to create a sense of entitlement among many of those who live illegally in the occupied West Bank. An alarming consequence is an increasing trend in acts of terror perpetrated against Palestinian civilians by settlers. ${ }^{13}$ These acts of violence routinely include attacks on families and homes, intimidation and verbal abuse, the burning and uprooting of trees, slaughter of livestock, and assaults on places of worship and other institutions. Between 2005 and 2011, incidents rose by $315 \% .{ }^{14}$ In 2013 alone, 963 incidents were documented. ${ }^{15}$

As settlements are located in an area of Palestine where Palestinian security forces are forbidden from entering, ${ }^{16}$ Palestinian communities are wholly vulnerable to attack. Israeli military forces routinely turn a blind eye to such attacks, thereby creating a culture of impunity, which allows settlers to commit crimes without consequence. A study carried out by the Israeli human rights organization, Yesh Din, found that $90 \%$ of investigations of Israeli attacks against Palestinians are closed without indictment. ${ }^{17}$

The radicalization of Israeli society has been no more clearly demonstrated than during the recent war on Gaza. At public demonstrations supporting the attacks on Gaza, the slogans "Butcher the Arabs" and "Death to the Leftists"18 have increased in a disturbing manner. Journalists have been physically attacked for criticizing Israeli government policy ${ }^{19}$ and photographs have been released of Israeli citizens sitting on a hillside, cheering as Gaza was bombed. ${ }^{20}$ On July 2, three Israelis kidnapped 16-year-old Muhammad Abu Khdair and took him to a forest

9 JPost: 'Bennett says his goal is to 'torpedo' any agreement with the Palestinians', January 2014

10 Haaretz: 'Netanyahu: I will not uproot a single Israeli', January 2014.

11 Peace Now, January 2007, http://peacenow.org.il/eng/content/quality-lifesettlers, accessed 19/08/14

12 B'Tselem, January 2014: http://www.btselem.org/settlements/migration, accessed 19/08/14.

13 In its 2011 'Country Reports on Terrorism', the US State Department listed acts of settler violence under 'terrorist incidents', http://www.state.gov/j/ ct/rls/crt/2011/195544.htm, accessed 19/08/14.

14 The Jerusalem Fund, 'When Settlers Attack', p. 2, 2012. http://www. thejerusalemfund.org/ht/a/GetDocumentAction/i/32678, accessed 19/08/14.

15 Palestine Monitoring Group, PLO NAD.

16 This is the area known as Area $\mathrm{C}$ under the Oslo accords, which constitutes approximately $61 \%$ of the occupied West Bank.

17 Yesh Din, February 2011, http://www.yesh-din.org/postview.asp?postid=150, accessed 19/08/14.

18 I24news, 'Clashes between Israelis over Gaza War', July 2014.

19 The Telegraph, 'Far-Right extremism on the rise in Israel as Gaza conflict continues', July 2014.

20 The Guardian, 'Israelis gather on hillsides to watch and cheer as military drops bombs on Gaza', July 2014 
where they tortured him and then burnt him alive. ${ }^{21}$ It is in this context that a peaceful solution must now be found.

\subsection{The benefits of siege: Gaza's role in the so-called 'conflict'}

There are differing narratives as to the timeline of events leading up to Israel's most recent military assault on Gaza. Some have pointed to the abduction, on June 12, and subsequent murder of three Israeli settlers in the West Bank as the immediate cause. The broader context, however, points convincingly to the use of this incident a pretext for the escalation of an ongoing and steady assault on Gaza, since Israel besieged the area almost ten years ago.

The Gaza strip has been subjected to severe Israeli bombardment on three separate occasions in the past six years. Prior to the most recent attack on Gaza, a number of Palestinians were killed and injured throughout the West Bank and the Gaza Strip. For instance, on July 1, a teenager was shot and killed by Israeli forces in Jenin refugee camp in the northern West Bank. On June 27, 23-year old Mohammed al-Fasih and 25-year old Usama al-Hassumi were killed through a targeted air strike near a refugee camp in Gaza. ${ }^{22}$ On May 15 , two teenagers were shot in the back during a demonstration, an incident that was filmed by the American news broadcaster CNN. ${ }^{23}$ During the most recent negotiations, between July 2013 and April 2014, 61 people were killed by Israeli forces. The list goes on, and totals 4744 in the past ten years alone. ${ }^{24}$

Violence against civilians is not to be condoned under any circumstances. However, to suggest, as some have, that Hamas is the aggressor against a state trying to live in peace, and to discount the effects of constant and unrelenting oppression and aggression from an occupying power in perpetuating violence, is unconvincing. In a similar way, some portray Israel as a state surrounded by hostile nations. Since 2002, the 'Arab Peace Initiative' has offered normalised relations with $57 \mathrm{Arab}$ and Islamic states in return for an Israeli withdrawal to the 1967 borders and a just solution to the refugee issue, in accordance with international law. An opportunity for security within the Middle East and beyond has been on the table for over ten years.

The current war on Gaza was preceded by two significant events, which should be considered, in order to understand the broader political context. The first event was the failure of the most recent US-sponsored negotiations. After nine months, no party could claim that progress had been made on any of the final status files and the Palestinian team berated the Israeli team for failing to produce a map of its proposed borders for a two-state solution. During this period, the Israeli government announced 14000 new settlement units and continued to carry out violent and oppressive measures against Palestinian civilians. ${ }^{25}$ Israel's

21 The unprovoked kidnapping and murder of Abu Khdair is said to have been a revenge attack following the kidnapping and murder of three settlers in the West Bank the previous month.

22 Haaretz, 'Israeli airstrike kills two Palestinian militants in Gaza Strip', June 2014.

23 CNN, 'Palestinian youths shot dead on camera', May 2014.

24 Palestine Monitoring Group, PLO NAD. The Israeli human rights organization, B'Tselem, puts the number at 6750 (between June 2004 and April 2014), http://www.btselem.org/statistics, accessed 19/08/14.

25 PLO NAD, 'Israeli violations during the nine month negotiations process', April 2014. refusal to release the final group of pre-Oslo prisoners on March 30 , as agreed at the beginning of the talks, dealt another blow to the negotiations process. The PLO regarded these actions as lack of will from the Israeli side.

The team of US Secretary of State John Kerry returned to the US with neither a comprehensive nor framework agreement. At this point, the US administration could no longer avoid criticising Israel. Kerry and other senior US officials referred to the ongoing building of settlements as one of the main factors contributing to the failure of talks. ${ }^{26}$ Kerry also warned against Israel taking a path towards Apartheid ${ }^{27}$ and international isolation. ${ }^{28}$ This criticism, from one of Israel's closest allies, signaled a slight shift in terms of the international community's willingness to tolerate the intransigence of Netanyahu's government.

The second noteworthy event to precede this latest assault on Gaza was the Palestinian formation of a unity government, after consultation with Hamas and other parties. This government, made up of independent technocrats and adhering to the political program of the PLO, was internationally welcomed, despite PM Netanyahu's efforts to prevent recognition. ${ }^{29}$ The US administration's recognition, in particular, was perceived to be another blow to Israel, which, having been exposed as primarily responsible for the failure of negotiations, also stood to lose the pretext of Hamas as a reason not to make peace.

As an occupying power, Israel has the ability to tighten and relax its control of West Bank and the Gaza Strip at its will. Indeed, the Israeli army employs a strategy openly described as 'mowing the lawn', meaning to subject Gaza to heavy attack every so often, with the purported goal of keeping Hamas' capabilities limited. ${ }^{30}$ On this latest occasion, some countries around the world refused to accept the narrative of 'self-defence's1 as justification for Israel's massacre in Gaza. In Europe, however, this narrative was largely accepted by journalists, politicians and governments alike.

Over a month later, over 2000 Palestinians (including almost 500 children) are dead and almost 10000 are injured, the vast majority civilians. On the Israeli side, three civilians have been killed as a result of rocket fire from Gaza. Aside from expressions of concern regarding the number of civilians killed, European discourse has focused almost wholly on Israeli security. Security for Palestinians is seldom discussed, despite repeated violations of life, liberty and security of person, and even when on such a vast scale as the past six weeks. For the Israeli government, 'mowing the lawn' and creating a diversion from reaching a two-state solution, while remaining unaccountable for its massacre in Gaza, is a cost-benefit calculation that appears to have worked out.

26 Ynet, 'Inside the talks' failure: US officials open up', May 2014.

27 The Daily Beast, 'Exclusive: Kerry warns Israel could become an 'Apartheid State", April 2014

28 New York Times, 'Netanyahu criticizes Kerry over boycott remarks', February 2014.

29 Reuters, 'Netanyahu urges world not to recognise Palestinian unity government', June 2014.

30 Rabani, M. 'Israel mows the lawn', London Review of Books, vol. 36, no. 15 , July 2014.

31 Particularly a number of South American countries: Brazil, Chile, Ecuador, Peru and El-Salvador recalled their ambassadors to Israel; Venezuela issued harsh criticism of Israel's assault on Gaza; Bolivia revoked its visa waiver program for Israeli citizens; and Argentina withdrew citizenship from its dual citizens serving in the Israeli military. 


\subsection{The profits of occupation: Exploitation of resources in the West Bank}

Israeli settlements, built unlawfully throughout the occupied State of Palestine, ${ }^{32}$ expropriate resources such as land, water, non-renewable resources such as stone, touristic sites, artifacts and cultural property. Israeli exports to Europe are worth 230 million euro per year from its illegal settlements alone. ${ }^{33}$ This is the equivalent of importing 100 times more per settler than per Palestinian. ${ }^{34}$ Around $70 \%$ of grapes produced by the Jordan Valley settlements are directed for export and make up approximately half of all grapes exported by Israel. ${ }^{35}$ Through quarries in the West Bank, which are operating in violation of international humanitarian law, Israel pillages 12 million tons of stone per year. ${ }^{36}$ The Dead Sea is a multi-million dollar tourist and beauty product industry, which Israel exploits in full. ${ }^{37}$

For Palestine, Israel's prolonged occupation is rather more costly in a number of ways. A study carried out in 2011 estimated the total economic cost of Israel's occupation to Palestine, which, at almost 7 billion USD, is a staggering $84.9 \%$ of the GDP of Palestine. ${ }^{38}$ The denied potential inflicted by Israel's occupation is also the primary reason why the Palestinians are so dependent on foreign aid.

In terms of quality of life, the occupation, through various manifestations such as the annexation wall, the settlements, bypass roads built for the use of settlers, and severe movement restrictions on the Palestinians, deny Palestinians their most basic human rights. The water situation provides a useful illustration. The World Health Organization recommends a minimum of 100 litres of water per person per day. The average Palestinian lives on 73 litres of water per day, while the average Israeli lives on approximately $300 .^{39}$

The profits of occupation, and desire for more land and resources, have led successive Israeli governments to avoid a two-state solution. If Israel is to be incentivised to end its decades-long occupation and work meaningfully towards a two-state solution, then the occupation must bear a cost.

\section{Potential Solutions}

\subsection{International involvement}

Given the reality of prolonged occupation, and the asymmetry between the two parties, the importance of international involvement becomes self-evident. The lack of will on the part

32 See primarily Fourth Geneva Convention, Article 49 and UNSCR 446 in this regard.

33 FIDH, 'Trading Away Peace', Oct 2012, http://www.fidh.org/IMG/pdf/trading. pdf, accessed 19/08/14.

34 Ibid.

35 Ibid.

36 Yesh Din, March 2009, http://www.yesh-din.org/userfiles/file/Petitions/ Quarries/Quarries\%20-\%20Petition\%20ENG.pdf, accessed 19/08/14.

37 UNOCHA, 'Humanitarian factsheet on the Jordan Valley and Dead Sea area', February 2012.

38 The economic costs of the Israeli occupation for the occupied Palestinian territory, http://www.un.org/depts/dpa/qpal/docs/2012Cairo/p2\%20jad\%20 isaac\%20e.pdf, accessed 19/08/14.

39 Al-Haq, 'Water for only one people', 2013, p. 51, http://www.alhaq.org/ publications/Water-For-One-People-Only.pdf, accessed 19/08/14 of the stronger party, to reach a two-state solution, necessitates that incentives come from those who are able to provide them.

Practical needs aside, the international community has an independent responsibility towards Palestine. The UN Partition Plan of 1947 resolved to divide Palestine against the will of the Palestinian people, a move which ultimately led to the creation of the State of Israel..$^{40}$ Sixty-six years later, the inalienable rights of the Palestinian people, acknowledged and supported in Europe and beyond, are yet to be fulfilled. According to international law, the Palestinian people's right to self-determination is a peremptory norm that must be respected by all states. The International Court of Justice, in its Advisory Opinion on the Wall in 2004, also recognized the Palestinian right to selfdetermination as a right erga omnes (obligation of all), which makes its realization and protection the concern of all states. This has been reaffirmed in subsequent UNGA resolutions.

The international community and individual states, as well as regional groupings, such as the $\mathrm{EU}$, also have their own laws and policies relevant to the situation in Palestine/Israel. As a regional bloc which describes "[h]uman rights, democracy and the rule of law" as its "core values", the EU must ensure that it fully implements its own policy and adheres to its own legislation.

\subsection{Operationalising policy: Towards a more active European role}

The two-state solution is a project supported by Europe since its earliest days. In 1980, Europe recognized its 'special role' and made it clear that Israel must 'put an end to the territorial occupation which it has maintained since the conflict of $1967^{\prime}{ }^{41}$

European policy is guided by international law and particularly UN Security Council resolutions such as 194 (relating to the rights of refugees), 242 and 338 (relating to Israel's need to withdraw to 1967 borders), and 476 (relating to non-recognition of any attempts to change the status of Jerusalem). Using the guidelines set by international law, and as a result of international consensus on the two-state solution, all countries (except Israel itself) have a clear policy on Israel's occupation and ongoing colonization of Palestinian land through its unlawful settlement enterprise.

A two-state solution requires two states. In 1999, the Berlin Declaration made an explicit commitment to the recognition of Palestine as a state. ${ }^{42}$ Although, in November 2012, 138 of 194 UN member states voted in favour of a resolution that recognised Palestine as a state on the 1967 borders, there are still a number of states which are yet to recognize Palestine bilaterally. Many countries have invested heavily in this solution, mostly in terms of humanitarian aid. Without a

40 The Partition plan is sometimes used to portray the Palestinians as rejectionists, based on the argument that the UN resolved to give approximately 55\% of Palestine to the Zionists to create a Jewish State, while Israel now exists on $78 \%$ of the land of historical Palestine, and occupies the rest. This is an anachronistic reading of history. The UN proposal was to divide a country belonging to one people and hand over more than half of its land to another group of people, the vast majority of whom had immigrated recently from abroad. Understood in its proper context, it is not difficult to see why the Palestinians rejected this imposed solution, citing the UN Charter with regard to peoples being allowed to decide their own fate.

41 'The Venice Declaration', June 1980.

42 'The Berlin Declaration', March 1999. 
political solution, however, taxpayers' money will continue to be wasted, due to the economic ceiling placed on Palestine by Israel's ongoing occupation.

A more active political role is required. In terms of the immediate situation in Gaza, European countries should take the initiative to support any ceasefire by helping to ensure robust terms, which address the core issues and prevent the repetition of such violence, which has claimed the lives of thousands. This includes: lifting the siege on Gaza within the context of the realisation of territorial contiguity and independence of the occupied State of Palestine; international monitoring; and robust enforcement mechanisms to ensure accountability for both parties.

In terms of the wider occupation and the realisation of the twostate solution, a number of steps can be taken. These include: bilateral recognitions from those who are yet to recognise Palestine; a greater and more multilateral role in mediating any negotiations process; and support for diplomatic steps taken by Palestine within the international arena. Finally, the operationalisation of existing European policy and implementation of international, regional and domestic law will also help both parties work towards the two-state solution, by reinforcing the 1967 borders as a basis for a negotiated solution. It is to this final issue that we now turn.

In July 2013, the European Union published a set of guidelines prohibiting EU prizes, grants and financial instruments from benefiting Israeli entities within the territories occupied in 1967, namely the settlements. The guidelines were born out of European policy, based on international law, ${ }^{43}$ which stipulates that the EU does not recognise expressions of Israeli sovereignty in areas occupied since $1967 .{ }^{44}$ The publication of the guidelines was therefore a natural translation of the EU's declarative policy and the result of the full and effective implementation of its own legislation.

The EU guidelines were a positive step, which the PLO welcomed as a factor in its decision to return to a negotiations process that had thus far failed to yield results, except for the detrimental outcome of increased settlement activity. The guidelines were a signal that Europe was beginning to more actively support the two-state solution, the end goal of negotiations as envisaged by both the Palestinian leadership and the international community. Unfortunately, little has followed on an EU-wide level. The repeated failure of negotiations should encourage more to be done, rather than less, in order to allow for the realisation of the two-state solution, before that solution is no longer possible.

The UN Guiding Principles on Business and Human rights (UNGP) set the international standard for corporate social responsibility. In March 2014, 46 out of the 47 members of the UN Human Rights Council $^{45}$ voted in favour of a resolution which urged all states to 'ensure that they are not taking actions that assist the expansion of settlements or construction of the wall in the Occupied Palestinian Territory, including East Jerusalem; and to provide information to

43 The ICJ Advisory Opinion (2004) stated: “All States are under an obligation not to recognize the illegal situation resulting from the construction of the wall and not to render aid or assistance in maintaining the situation created by such construction...".

44 European Council Conclusions on the MEPP, December 2012

45 Including all nine EU member states (Austria, the Czech Republic, Estonia, France, Germany, Ireland, Italy, Romania, and the UK). individuals and businesses on the financial, reputational and legal risks, as well as the possible abuses of the rights of individuals, of getting involved in settlement-related activities, including economic and financial activities, the provision of services in settlements and the purchasing of property.'

A number of states have begun to adhere to these principles, either by publishing warnings on government websites or adopting some form of official discouragement policy. In Europe, this now includes a total of 17 countries: Austria, Belgium, Croatia, Denmark, France, Finland, Greece, Ireland, Italy, Luxembourg, Malta, Netherlands, Portugal, Slovakia, Slovenia, Spain and the UK.

In some specific cases, states have also intervened to ensure compliance with such standards. To give just two examples: In 2011, the German national rail company, Deutsche Bahn, pulled out of an Israeli train line project that was planned to cut into occupied Palestinian land in two places, following a letter from Germany's Transport Minster to the CEO of the company. ${ }^{46}$ In 2013, the Dutch government intervened to discourage a Dutch wastewater company, Royal Haskoning, from engaging in a project in occupied East Jerusalem. ${ }^{47}$ These measures should be evolved into a more active and systematic effort on behalf of states to ensure that their public and private companies are informed and discouraged from directly or indirectly supporting Israel's settlement enterprise and its associated abuses of human rights. This involves ensuring that no company operates in, or has contracts with, settlement enterprises, in addition to not purchasing goods or services from Israeli companies that are complicit in Israel's settlement regime.

Steps like this will ensure that states and other actors are adhering to their own policies, as well as domestic, regional and international law. At the same time, operationalisation of policy will help to support the realisation of a two-state solution, by making Israel's settlement enterprise less profitable. This will encourage Israel's government to create the necessary political will in order to return to the negotiating table with more incentive to end its occupation and finally allow for two states to live side by side in peace and security.

\section{Conclusion}

At times like this, when so many innocent civilians have lost their lives and the rest are returning to rubble for the third time in six years, active political effort is more necessary than ever. History has taught us that this situation will not be solved militarily, will not be solved as long as the imbalance between occupier and occupied is ignored, and will not be solved without international pressure on the stronger party. Only peace will bring true and lasting security. And only justice and equality, for all who live in this land, will bring peace. The international community has the ability, and hopefully the will, to achieve this.

46 Letter from Dr. Peter Ramsauer to Dr. Rüdiger Grube, http://www. bdsmovement.net/files/2011/05/110216_Ramsauer-to-DB_Grube_DE_ EN.pdf, accessed 19/08/14.

47 ECCP, 'The contribution of European Businesses to the existence and expansion of illegal Israeli settlements', 2014, http://www.europarl.europa. eu/meetdocs/2009_2014/documents/dplc/dv/illegal_israeli_settlements/ illegal_israeli_settlementsen.pdf, accessed 19/08/14. 